\title{
The Ethics of Repair: Re-animating the Archive
}

\author{
Sean Cubitt \\ in Pepita Hesselberth \& Maria Poulaki (eds), Compact Cinematics: The Moving \\ Image in the Age of Bit-Sized Media. London: Bloomsbury. 57-63.
}

When we consider archives, we should consider not only how we recall the dead, but how they recall us.

Archive footage and found footage films are a significant sub-genre of the compact cinema addressed in this book, from Len Lye's exquisitely over-painted library footage in Trade Tatoo (1937) and Joseph Cornell's Rose Hobart (1936) to Bruce Connor's A Movie (1958), Ken Jacobs' Tom, Tom, the Piper's Son (1969), the scratch videos of George Barber and the contemporary collages of Craig Baldwin, and many music video makers. In the intensity of their channelling of the past, these bursts of reworked history raise particular questions for compact cinematics.

How does ethical obligation operate across temporal disjuncture? How does archival obligation relate to the dominant regime governing time today: debt. Debt as gratitude is a universal of human experience binding us to each other and to the earth. Debt as universal economic peonage ejects us emotionally and legally from the social, and poisons our relations with nature. Debt ties us to a model of time: what we consume today has to be repaid in the future; or rather, the principle is never repaid, but we commit to perpetual payment of interest on it. In this debt sublimates and perverts the principle of obligation. Archive ethics have a special role to play in urging us to consider ourselves as media through which the ancestral archives transmit themselves into a future other than that of perpetual indebtedness.

Archived works come toward us as alien, or at least as orphaned. We greet them not only as evidence of a lost world but also as technical artefacts. Their technicity confronts us. The otherness of the archival film or video comes towards us as a stranger, a technical thing: its substrates and its acquired damage. This object presents itself as fragile. As a fragile, damaged object, it stands before us in need.

In Levinas' (1969) account of ethics as first philosophy, the encounter of 
human individuals is always already ethical: when I face the Other, the Other places on me a demand for recognition. In Simon Critchley's (2007) reworking of the thesis, the demand is infinite: I am obliged beyond reason to the Other. Something of this alterity drives the archival encounter. What I encounter is other than myself, yet has a life of its own which I feel bound to acknowledge. What confronts us is not just what is represented but the mediation, more physically present in archival material than in the ordinary media we tend to see through. Even more than the most formally selfreflexive works, archival encounters bring us face to face with fragile but living entities carrying freights both of the intentions of their makers and of the accidents that have occurred to them in their journeys through time. The archival thing is more than its freight of human motivations and symbols. It is a palimpsest of chemical and physical processes that occurred down the long years between its making and the meeting in the archive. The things we encounter are in this sense wholly technological.

Archives extend ethics beyond the interpersonal, humanist plane. For Levinas only the encounter with another human counts (and not for example with a film or televised representation), so that we only meet the other as a member of our species, a finally unknowable other who nonetheless shares with us a here and a now. The archival encounter, like the encounter with the recorded or broadcast image, is different in that the simultaneity and co-location are not guaranteed, and we do not meet our likeness in a member of our own species, but something other, ghostly, of another time and place. In preparatory work for his proposal of an ethics of encounter, Levinas addressed the artistic "obscuring of being in images" $(1989,142)$. Counter to Kracauer's or Bazin's redemption of physical reality, Levinas poses the image as stranded in a mythic "meanwhile," a time outside of becoming. Yet the archive image is always historical in this physical sense, vanishing or being remade. There is then an implication that archive footage has a privileged relation to becoming as forgetting and erasure, quite as much as an indexical relation to a once-real. Indeed, in witnessing the vanishing of the past in its own combination of recalling and losing, the archive trumps both humanist realism and formalist ontology in its encounter between human subjects and archival objects travelling in opposite directions through time, one acquiring memories, the other losing them.

Such is the encounter enacted for us in Marisol Trujillo's short film Oración [Prayer] (1984, 9 min.). Before the Revolution of 1959, Cuba was the major centre 
for US film distribution into Latin America. The Insituto Cubano del Arte e Industria Cinematográficos (ICAIC), as combined film school, production house, and distributor, took over that archive and made it available for educational, critical, and study purposes. Trujillo's nine minute film dips into features and newsreels for images of Marilyn Monroe, which she accompanies with a poem of the same title (Oración) by the Nicaraguan Sandinista poet Ernesto Cardenal, written and read, with great passion, by the Cuban actor José Rodríguez. Music video is typically commissioned to accompany a music track already recorded. Trujillo takes Cardenal's reading as her source text, punctuating his plea to God to consider his servant Norma Jean Baker (Monroe's real name), and using images from then recent Vietnam and Biafran wars to underpin the global reach of Cardenal's verse. In the opening stanza, instigating the practice of the whole film, Trujillo constantly reframes the found footage and stills, culminating in a rotation of the famous Monroe Playboy nude spread focusing on her face until it cross-fades to that of a starved victim of the Biafran genocide.

In the second stanza, after the title, Monroe disappears visually, even as Cardenal recounts and interprets a dream she recalled in a Time interview in which she steps carefully over the heads of her fans in order not to step on them. Trujillo here montages shots of colonial atrocities and fascism with protests against them, closing on the 20th Century Fox logo with US warplanes mapped against it.

The third stanza reads the church of Monroe's dream as the temple of her body, turned into a den of thieves by Fox, from which Christ drives the moneylenders. "Señor," his voice intones between pauses, as the montage of war and horror gives way to an early starlet image of Monroe's face. Surely God will forgive a shopgirl's dreams that turned into a technicolor reality, dreams that are also ours. Forgive us, he asks, for our 20th century, as Trujillo's montage moves across images of plenty that invariably include some corner of deprivation, and then a series of women's faces caught in anger, bewilderment and mourning.

The fourth stanza takes us into Monroe's growing mental instability and the emptiness of the drugs and therapies offered her, which in Trujillo's montage, by identifying her made-up eye with the eye of a slum child, extends to the scale of global event, surrounding Cardenal's account of her public celebrity with images of prostitution, drug addiction, begging and scavenging. The most luminous capture of the film, from the sequence of her racing to the yacht in full torch-singer costume in Some Like It Hot (Wilder, 1959), is composited with footage of a bridge swaying 
surreally during an earthquake accompanying the line "Her life was unreal," a shot that gives way to a slightly slowed footage of nuclear testing in the Pacific, that threat of final war which weighed so heavily in the politics of Monroe's lifetime, the period in the 1980s when Trujillo was working, and with which the name of Cuba was almost synonymous since the missile crisis of 1962.

And in the final stanza, with paparazzi shots of the apartment bedroom where Monroe died of an overdose, and a comparison of shots of her face ambiguously caught between sexual ecstasy and drug overdose with that of a newborn child in pain, Cardenal's poem asks who she was trying to call as she lay dying. While images of revolt and revolution mount, culminating in the image of a child reaching skyward, he demands "Señor, contesta Tu el telefono," "Lord, You answer the telephone." The strains of Blake's Jerusalem, in the setting by Parry (who assigned copyright in it to the National Union for Women's Suffrage), swell over images of children and revolutionaries, ending with a child in the pose of Blake's Glad Day. (According to an email from Michael Chanan, Trujillo knew nothing about the song, not even that the words were Blake's, but that it simply sounded right: intuition is as significant to the archival encounter as scholarship in generating new possibilities and meanings).

Aesthetics is the ethical matter of mediations through which we perceive and communicate our own happiness - or otherwise - and that of the worlds we inhabit, social, technological and 'natural'. Therefore the ethical-political question of the good life, even before we extend it beyond the human, is already a question of mediations and thus aesthetic; and doubly so when the aesthetic is the first mediation through which we become aware of the unhappiness - or otherwise - of excluded and nonhuman others, the moment at which aesthetics ceases to be individual and becomes political. Because it deals with the natural physical and chemical decay as well as the constraints of antique technologies, the archive operates in this aesthetic-ethicalpolitical zone as a special intersection between human and non-human, included and excluded, as encounter between individuals and polities, and between them and technological and natural environments, the living and the dead.

Trujillo's encounter with the Monroe of the archive is not, and could never be, an encounter with the real Norma Jean Baker. Transformed and transfigured in her own encounter with Hollywood, Monroe, in Cardenal's account, has already lost sight of her own reality. The archival encounter, moreover, is not with Monroe but with the image, precisely that image which in Cardenal is already occupied by the 
moneylenders, and in Levinas is already a betrayal of the real. Yet in Trujillo's film, the reality of Monroe's archive is not of her body as immaculate origin of the image but on the contrary, the star-making machine itself. In her montage, Trujillo undermines the Technicolor dream to show the brutality inflicted on this woman and all women and their children. There is no real to encounter, but the traces, already fading, of a hegemony that is also fading, and in despite of which the dream of beauty and freedom survive their desecration.

The demand the archive places is the demand of the irreplaceable. The archival ethic, then, is to save this specific copy. Increasingly dealing with the constraints of storage and restoration costs, archivists are faced with the choice of what it is that they are trying to conserve, the question of canon-formation, and the balance between preservation and access. Caroline Frick (2011) argues that the industry has had the lion's share of preservation and access, while, as Jane Gaines (2007) points out, there has been a tendency to ignore or sideline women's work - in a province where sidelining is in effect a death sentence. Many colonial films, African American films, and other marginalised practices have suffered equally. The work of the archive is as much one of systematic forgetting as it is of remembrance. In this, the archive participates in the logic of the image. Still photographs are ripped from the continuum of time. The moving image was invented as a way of healing that trauma, but can only do so on the principle that each frame is itself radically incomplete, necessitating the next image and the next. Every movie arrives in order to supplement and eventually to supplant every previous one.

It is not enough for Trujillo to preserve in this short film. The archive can in any case preserve only the current state of decay. Instead, Trujillo embraces and enacts the ethics of encounter, mediating the savage system that glorified and threw away Monroe for another generation to wonder at. That Oración is so difficult to find, with most copies now several electronic generations away from the cinema print, only emphasises that core truth of decay. By the time of her death, Monroe had already achieved the status of myth, moving from sports hero's wife to wife of the best-known intellectual of her day to the mooted mistress of the most famous US president of her century. It is this myth that we see in its decay, rather than the woman or the star: the myth of 20th Century Fox, the mythical time of suspended reality apart from a history which always reclaims it. Trujillo cannot retrieve the sufferings of Norma Jean Baker, or make amends for them, but only reach back into the rift in the real that images 
leave as their lasting legacy.

Under financialisation, debt spends today the earnings of the future, pledging us to repay, so committing us not only to work but to maintain the wage relation in perpetuity. In its very decay, the archive video that is its most commonly seen form demonstrates the morbidity, not of ephemerality, but of permanence, where permanence has become the permanence of finance. Because in each single frame we ineluctably miss the completion of flux in the present, Trujillo's handling of the archive footage seems to say, we owe our tremendous debt not to the future but to the past. If so, then the future owes us a debt, rather than us owing it. We are the ancestors who look to the future for our justification, the justification adumbrated in Trujillo's closing shots of children, symbols of hope and futurity. Just as we are the posterity who must somehow justify the massacres and atrocities evidenced in the newsreel footage, and the heroism of those who fought against them in other shots from demonstrations and battle scenes from Vietnam and Latin America. When the Playboy centrefold cuts to a child dead of malnutrition, the commerce of desire and of death beg us for a resolution. The aesthetics of archiving derive from this impossible task of bearing their truth to those for whom we also will in turn be ancestors.

The archivist's work is always melancholy, not because of nostalgia for an impossible original state of the archive object, but because the moving image's impetus to complete the rift in the real, instigated by the still image, inhabits the archive's impulse to return to origin while knowing it is impossible. What remains is to recognise the fact, subjective and objective, of torn time; to encounter the infinitely demanding Other of decay; and to transform that inevitability into a talismanic promise that the future will not be an unending duplication of the past. What the present encounter with Oración now archives is not the record of Monroe but of this unrepeatable archival encounter in ICAIC in 1984.

Since there is no God, and our posterity will no doubt be as fallible as we have been in our role as posterity to the past, it is the present audience, hearing, who must answer the telephone, who must accept the repayment offered by the past for the debts of the present. 